\title{
Determining Linguistic and Cultural Diminution: An Analysis of Urbanization and
}

\author{
Migration in Pakistan \\ * Dr. Muhammad Gulfraz Abbasi, Associate Professor \\ ** Dr. Muhammad Ahsan, Lecturer (Corresponding Author) \\ *** Dr. Zahoor Hussain, Lecturer
}

\begin{abstract}
Urbanization is a worldwide phenomenon in which people move to cities for multiple reasons. Before partition in 1947, the trend of urbanization in Pakistan was not so popular. However, after independence, this trend increased manifold. As urbanization increased, the migrants also started losing their precious native languages and other things related to culture. The present study also focuses on how the in-migration from rural to urban areas in Pakistan has caused a decline in the native language and culture of the migrants belonging to Murree. The sample of 142 people across the gender was selected from Murree, Pakistan. The participants had shifted to urban areas in the past and permanently settled in the city culture where Urdu, the national language was mostly dominant. The detailed open-ended ethnographic interviews of the participants revealed that the whole Pahari culture and Pahari language is under threat as a consequence of this urbanization.
\end{abstract}

Keywords: Urbanization, Pakistan, Partition, Native Language, Rural, Urban, Pahari

\section{Introduction}

The world is becoming a global village and all the countries of the world are connected in multiple ways with each other. This connection is increasing day by day as the population of the world is increasing along with an increase in new ways and methods of connectivity mainly due to the internet and social media. Initially, the speed of growth remained low but later it got momentum and in the present-day circumstances, approximately 73 million people are constantly added to the world's population every year (Macionis, 2006). With the growth of cities, urbanization also grows and it happens especially in the developing countries and Pakistan is no exception to that (Arif and Hamid, 2009). Moreover, the technological advancements have brought the people of this globe onto a single community. The technological advancements have not only squeezed the distances but also made this world a village where people have access to each other, despite the huge distances between them. This technological advancement is due to the growing education, growing awareness, and increasing interest in world affairs and new ways of earning. It has brought about the concentration of people who wish to live a multidimensional life as it is the demand of the cities. In Pakistan, the trend of migration is largely from rural to urban areas and that makes a total of 39 percent of the total movement (Arif \&Hamid, 2009).

Urbanization is the collection and concentration of people in the cities or urban areas (Macionis, 2006). Here people tend to come to make their life prosperous and be able to avail of the multiple opportunities that city life offers. The process of urbanization results in the physical growth of the urban area. A great inflow has been recorded in respect of people from the rural areas of the world to the cities and in this way; the volume of the cities is increasing tremendously. According to Gumus (2004), in 1950, thirty percent of the world's population was residing in the urban areas while in the year 2000, this average rose to 47 percent. By the year 2050, it is anticipated that 64 percent of the developing and 86 percent of the developed world will adopt the urbanized status. Around 2.7 billion people will move into cities by 2030 (Glaeser, Joshi-Ghani, 2014).

\footnotetext{
* Government College Murree, Pakistan Email: gulfrazabbasi@gmail.com

** Department of English, Ghazi University Dera Ghazi Khan, Pakistan Email: mahsan@gudgk.edu.pk

*** Department of English, Bahaudin Zakariya University, Layyah Campus, Pakistan

Email: zahoor_linguist@bzu.edu.pk
} 
This trend was not very popular around 67 years ago when Pakistan had not come into being yet. It was a time when most of the people were illiterate and uneducated and most of the people were having their abode in the rural areas of Pakistan. They would cultivate their lands, had their livestock, and would live a simple life. After the independence of Pakistan, people gradually started coming to cities for jobs. It was usually the trend of the families to have one member of the family (necessarily a man) in the city to earn some money so that they could buy consumable products that they could not produce on their farms. Otherwise, they would focus on producing things for their household use in their local farm fields. It was also a popular sentiment that cities were the hub of obscenity and that life in cities was artificial. Most of the rural population did not like the urban way of living.

Then a time came when people mainly those who did not have their property and were oppressed by the landowners in the environment of villages started coming to the cities to safeguard themselves from the feudal system so that could play on the opportunities city life offer could also keep themselves away from the influences of the feudal. In this way, they could get rid of the landlord's oppression in the villages besides getting economic benefits. So each new day came in their lives with a more promising future. This gave a trend to the people of the rural areas to migrate to the cities for better prospects. In Pakistan urbanization has assumed a serious threat because it is estimated that the urban population will rise by around 140 percent in 2030 (Haider, 2006). According to Haq, the rate of urbanization in Pakistan among the South Asian countries is now the highest, and by the end of 2030, its urban population is supposed to be equal to its rural population (2009). He also estimates the data for 2005 which shows the level of urbanization at 35 percent. The population of urban areas as was recorded in the census of 1998 was approximately 43 million while the calculations made in 2009 reveal it to be 57.3 million (Illahi, N.A). But still there was a majority of the people who did not like to move to settle down in the cities. They think that they would not be able to cope up with the demands and pressures of the city life. In rural areas of Pakistan, a handsome majority of the people are landless (World Bank report 2002). According to them, they were unable to start their life from the very beginning. There, in the villages, they had cattle, crops, vegetables, etc. of their own. If they did not earn money in the cities, even then, they could survive. But according to them, survival in the cities was hardly possible for them. When migration takes place, the labor force relinquishes the agriculture and merges into non-agricultural groups (Memon, 2006).

Culture and language are interdependent elements in any society. Both reflect each other. Language carries the store of a culture and a culture stores the fundamentals of a language (Assemi $e t$ al., 2012). The higher the urbanization grows, the higher the shift in native language increases (Ishtiaq, 1999). According to him, there is a direct relationship between language shift and urbanization. Kashmiri (2006) gives examples of the folk literature present on the hills of Murree and how it is being eroded and swept away with the wave of urbanization and modernity. According to him, with the coming of new media, new networks, and communication revolution, the trend of old folk songs are giving way to the new Indian songs. In the past, there was a trend of telling indigenous folk tales to each other. People had enough time to make and tell these stories. The nights used to belong and they had no alternative except to tell stories, riddles, and horror stories. The new generation is not equipped with that knowledge because they are learning new languages like Urdu and English instead of their native Pahari language which had a reservoir of that knowledge (Abbasi \& Asif, 2010). As a result, the community elders are unable to transmit the culture and its precious attributes to the coming generations. In such a situation, it is highly necessary to document whatever is left and discuss it in detail and preserve it for future use of the generations to come. So the trend of urbanization, along with other problems, has been instrumental in changing the lifestyle of the people and their way of thinking. Consequently, we find a great difference in the approach and thinking of the people who shifted to urban areas.

\section{Significance of the Study}

The study is significant because it takes into consideration important changes taking place in Pakistani society. The mass migration from the rural areas to the urban areas cannot be ignored and along with this movement, there are related changes in the lives of the people and these cannot be ignored as well. The study is important also because it uncovers certain areas of urban life that allow its inhabitants to leave their culture and language behind with other migration to cities. It also focuses on the loss of culture and language as a result of urbanization. The study can help in creating awareness that culture and language are the most important things which can be protected along with history and 
traditions. If we lose this, we cannot protect other things related to it. The whole repository of literature and folklores will die out.

\section{Aim of the Study}

The study aims to find out the following elements;

- $\quad$ The problems faced by the rural population which ultimately motivate them to migrate

- $\quad$ Cultural and linguistic changes which have been occurring due to migration

- Awareness of the people regarding the loss of their culture and linguistic heritage

- $\quad$ Efforts for the preservation of the native language and culture.

\section{Research Questions}

Following research questions will help in this study;

- How the native Pahari language of the Murree area is in decline due to this urbanization and migration to the cities?

- How does the cultural knowledge among the three generations decrease due to urbanization?

- What kind of folk literature and other related things remain preserved even after migration to the cities and why?

\section{Introduction to the Sample}

When the discussion about the culture and overall tendencies of the people is initiated, the South Asian perspective cannot be ignored. Almost all countries such as India, Bangladesh, Sri Lanka, Nepal, and Pakistan have the same system of migration. The urbanization trend is almost the same in all these countries and it is increasing day by day in these countries. In Pakistan, the cities are getting bigger and bigger due to the constant migration of the people from the villages to the urban areas. The small towns are getting bigger and taking the shape of big cities. In this context, we have chosen one sub-district of the province Punjab. The name of this Tehsil [sub district] is Murree. It is situated in the north of Punjab bordering the frontier province Khyber-Pakhtunkhwa [KPK]. The population of this area is described differently by different researchers. It is a hill resort where tourists from different parts of the country and abroad come for spending holidays. The urban part of this area is very small; however, the rural part is very big. These people not only migrate to Murree city but also Rawalpindi district and Islamabad. They set up their businesses and try to permanently settle there. Not only this area but also the residents of other surrounding areas of Rawalpindi and Islamabad are also shifting to these twin cities for better living and better prospects.

To get first-hand knowledge of the culture and people we succeeded in interviewing 142 respondents and from this huge bulk, 14 tables were organized from this community of Murree to see the ultimate trends of the migration and the expected benefits that these people wanted to achieve after migration. The researchers had to move to Rawalpindi and Islamabad too to meet with these people and to be in their families for some time. Most of the time, we were successful in finding their families, and in some cases, we met with the male members of different families outside of their houses. We interviewed them informally during lunch or tea. But the primary focus was to explore the cultural background of the people of this area and to know how they were affected by this migration and urbanization. Moreover, the suburban rural areas of Murree were also passing through development stages and receiving the benefits of Urbanization. It was mostly because of the construction of roads and the supply of natural gas to these areas that a change in the attitude of these people occurred.

\section{Methodology}

Researchers have collected data through ethnographic structured interviews. Ethnography is a method in which the researchers can mix themselves in the community where they want to undertake research. In ethnographic research work and fieldwork, an investigator engrosses him/her/ in the data scattered in the field by becoming a necessary part of that data and the purpose is to find the social interpretations and meanings of the attitude and behavior of the spontaneously occurring actions (Jorgensen, 1989). Moreover, ethnographic research is originally based on exploratory nature and sometimes it requires an investigator to work in the field for a long time. Its distinctive quality is that the culture is truly revealed and the researcher can find out and observe each minute detail. The interviews are also not limited and restricted. They allow the researcher to ask questions and expand them according to the situation. He may change the set pattern of questions if the need arises. 
In the case of the present study, ethnography has been very supportive in interpreting the culture, traditions, and language of the community. The researcher wanted to see the socio-economic situations and circumstances of language and cultural artifacts. We also wanted to see how far these people have kept up the language and preserved it. So we interviewed the people from three generations to get the views of the people regarding their culture and language. We wanted to check whether the use of language and indigenous culture is decreasing or it is still safe. For ethnographic structured interviews were used with a voice recorder and diary. We kept the notes which we recorded from our observation. We also listened to the recorded interviews and transferred the results on paper. Analysis

The analysis of the interviews shows that urbanization and in-migration to cities has brought about a great change in the lifestyle of the people. Economically and socially they feel secured and they are living a happy life if we compare it to that of their village life. We shall discuss each question separately to make the things clear.

Table 1

Reason of Migration

\begin{tabular}{cccccc}
\hline Participants & $\begin{array}{c}\text { Economic } \\
\text { Issue }\end{array}$ & $\begin{array}{c}\text { Family } \\
\text { Issues }\end{array}$ & $\begin{array}{c}\text { Oppression in Rural } \\
\text { Society }\end{array}$ & Culture Hate & Others \\
\hline Men & $49 \%$ & $16 \%$ & $20 \%$ & $8 \%$ & $7 \%$ \\
Women & $58 \%$ & $30 \%$ & $4 \%$ & $7 \%$ & $1 \%$ \\
\hline
\end{tabular}

This was our first foremost question from the respondents. We got multiple responses. There were several reasons which motivated people from Murree to shift to Rawalpindi and Murree city area. These include primarily their economic issues. The so-called low castes especially had no proper residences of their own, nor did they have any land to cultivate. If they were to cultivate, they had to give a big chunk to the landlord. This economic issue resulted in family feuds too. Other than that, they had to face the oppression of the landlord, although it is very rare in the rural areas of Murree nowadays. However, it used to happen in the past. Another significant thing that came under discussion was the hate trend among the people for their own culture and its artifacts. When we asked them why they had this hatred, the answer in many cases was the less effectiveness of Pahari culture. It had no prospects. The above table clearly shows that the major cause of migration to the cities was socio-economic problems, however, the other issues like culture dislike and oppression by the upper castes are also one of the factors of in-migration.

\section{Attraction in Urban Life}

The table below shows the attraction that the people felt when they decided to come and adjust to the cities. It is very difficult for the people of Murree rural to migrate. It is not basically in their nature to leave their abode for good. They are conservative people. It must have reasons colossal enough to compel them to take this step. When they got fed up with rural life and found attraction in urban life, they decided to leave for the cities. The following table clearly illustrates how they were attracted to the amenities of life found in the city life. They had better prospects of education for their children in the city life, unlike their village life. They could avail of better transport.

Table 2

\begin{tabular}{ccccccc}
\hline Participants & $\begin{array}{c}\text { Better } \\
\text { Transport }\end{array}$ & $\begin{array}{c}\text { Better } \\
\text { Education }\end{array}$ & $\begin{array}{c}\text { Freedom of } \\
\text { Vote }\end{array}$ & $\begin{array}{c}\text { Less Family } \\
\text { Feuds }\end{array}$ & $\begin{array}{c}\text { Health } \\
\text { Facilities }\end{array}$ & $\begin{array}{c}\text { No Caste } \\
\text { and Creed } \\
\text { Pressure }\end{array}$ \\
\hline Men & $90 \%$ & $100 \%$ & $87 \%$ & $57 \%$ & $67 \%$ & $90 \%$ \\
Women & $95 \%$ & $100 \%$ & $90 \%$ & $45 \%$ & $70 \%$ & $92 \%$ \\
\hline
\end{tabular}

They could avail of health facilities at their doorstep. Moreover, if someone belonged to the so-called low caste, the pressure was released when they came to cities where everyone lived his/her own life. So these acts of freedom and facilities attracted the people to come and adjust in the cities. The following table will illustrate the family values and their retention.

Table 3

Retention of Family Values

\begin{tabular}{ccc}
\hline Participants & Yes & No \\
\hline Men & $28 \%$ & $72 \%$ \\
Women & $35 \%$ & $65 \%$ \\
\hline
\end{tabular}


142 participants indicated in this interview that they could not retain the family values. Almost a quarter of the participants said that they had retained the family values. Three fourth of them believed that they had merged themselves into a different culture and tradition. This shows that urban life has undergone a change and their lifestyle also transformed to a great extent. The following table gives us an idea of social networks that they retain or do not retain after migration to the cities.

Table 4

Retention of Social Networks

\begin{tabular}{ccc}
\hline Participants & Yes & No \\
\hline Men & $48 \%$ & $\mathbf{5 2 \%}$ \\
Women & $\mathbf{3 4 \%}$ & $\mathbf{6 6 \%}$ \\
\hline
\end{tabular}

This table shows that the people who migrated to the cities also lost a considerable chunk of their networks. In their interviews, they talked about their social networks which they enjoyed while being in the rural areas. Men have maintained their networks in one way or the other; however, the women's views are quite different. They lost their connections while being in the urban areas. Most of the women were housewives and they tended to remain inside their houses unlike their life in the rural areas where they used to move outside of their houses and meet with other women. However, they established different kinds of networks from the urban area. The following table illustrates social change and modernization.

\section{Social Change and Modernization}

The participants showed that they embraced change after absorbing themselves in the urban way of living. This change was of course automatic and they could not succumb to it. They believed that their resistance would have proved futile if they had fought against the currents of modern city life.

Table 5

\begin{tabular}{ccc}
\hline Participants & Yes & No \\
\hline Men & $60 \%$ & $40 \%$ \\
Women & $65 \%$ & $35 \%$ \\
\hline
\end{tabular}

Interviews of the study revealed that the people who migrated to the cities adopted social change. They also accepted the modern trends found in the cities. This is not limited to only one side. It is something which was related to other reasons too. All the reasons were intertwined with each other. It was difficult to disentangle one from the other. In the same way, people opined that they adopted change and became modern as they started living in the cities.

Ills of Urbanization

Table 6

\begin{tabular}{ccccc}
\hline Participants & Monetary Race & Drugs & Environmental Problems & Crimes \\
\hline Men & $80 \%$ & $31 \%$ & $43 \%$ & $42 \%$ \\
Women & $63 \%$ & $20 \%$ & $23 \%$ & $41 \%$ \\
\hline
\end{tabular}

All the participants of the study had the cognizance of the negative aspects of urbanization. Although, independently speaking, urban life also had its culture and traditions, but the major problem was the loss of culture, traditions, and customs of the people. They know that the demands of the cities transformed them and they could not resist changing themselves. They mentioned that in the cities the biggest problem was the race of money and wealth. There was always a danger of drug addiction by the youth if they stayed outside of their homes for quite some time. They also admitted that the crime rate was high and especially in the recent years it grew tremendously. They also talked about the polluted environment of the cities. So despite all these negative points, they lived in the cities for certain benefits which were strong enough to beat its weak points.

The following table describes the views and ideas of the participants regarding the maintenance of their indigenous Pahari language after they migrate to the cities.

\section{Maintenance of Pahari language}

\section{Table 7}

\begin{tabular}{ccc}
\hline Participants & Yes & No \\
\hline Men & $31 \%$ & $69 \%$ \\
Women & $26 \%$ & $74 \%$ \\
\hline
\end{tabular}

Language is an important part of culture. It is a tool through which culture speaks. These two things are intertwined with each other. The loss of one thing results in the loss of the other. The participants both men and women believed that language preservation was not possible in the cities. 
Hardly 31 percent male and 26 percent female people believed that it was maintained. However, it was hardly possible for the families living in the cities to remain isolated and not be impressed by the environment. The following table illustrates the effect of urbanization on the native language and how it shifted towards Urdu which is the national language of Pakistan.

\section{Reasons for Language Shift}

Table 8

\begin{tabular}{ccccc}
\hline Participants & $\begin{array}{c}\text { Language } \\
\text { Dislike }\end{array}$ & $\begin{array}{c}\text { Economic } \\
\text { Problems }\end{array}$ & Network Shift & $\begin{array}{c}\text { Education / } \\
\text { Schooling }\end{array}$ \\
\hline Men & $15 \%$ & $25 \%$ & $46 \%$ & $62 \%$ \\
Women & $30 \%$ & $16 \%$ & $50 \%$ & $60 \%$ \\
\hline
\end{tabular}

As the table above shows, the participants considered the modern education in schools as the major killer of the native language. It means that they spoke their native language but their children attending schools were not taught the native language, all this shows language dislike. Instead, it is discouraging. So, both men and women considered it a threat. The second threat is the change of networks. When they shifted to the cities, they had to interact with other people speaking different languages and dialects. This naturally caused the language shift. So a quarter of the people also considered that economic problems or language shame were responsible for language decline. The below table explains the living style of the people who came from the rural areas and were now settled in the urban areas, whether they retained the old living style or brought about a considerable change in that.

Living style

Table 9

\begin{tabular}{llllll}
\hline Participants & $\begin{array}{c}\text { Modern } \\
\text { (Urban) }\end{array}$ & $\begin{array}{c}\text { Old ( Rural } \\
\text { Like) }\end{array}$ & $\begin{array}{c}\text { Not old not } \\
\text { New }\end{array}$ & Car / Motorbike & Parties/Birthdays \\
\hline Men & $67 \%$ & $12 \%$ & $21 \%$ & Yes, 73\% & $25 \%$ \\
Women & $70 \%$ & $08 \%$ & $22 \%$ & Yes, 74\% & $33 \%$ \\
\hline
\end{tabular}

According to the people from my sample, more than 60 percent adopted the modern urban style of living after they migrated to the cities. A very few people said that they still maintained the old living style. These were the people who lived in the periphery of the cities and had to still rely on livestock and milk supply etc. A large number of people had bikes, some had cars too. Twenty-five percent of men and 33 percent of women also said that they would hold parties on certain occasions while it was not a customary thing in the village life.

How much the income changed when these people moved to the cities is manifest in the following table.

\section{Change of income in the urban area}

Table 10

\begin{tabular}{ccc}
\hline Participants & Increased & Decreased \\
\hline Men & $85 \%$ & $15 \%$ \\
Women & $80 \%$ & $20 \%$ \\
\hline
\end{tabular}

When asked whether they increased their income after coming to the cities, most of them said that their income did increase. A very few said that their income decreased. These people were living in the rented houses and they could not succeed in establishing any business, or they failed in one way or the other. However, mostly the migrants considered it a good omen that they came to the cities. It improved their lifestyle and increased their income. In the following table, we tried to show the views of the participants about their native language.

\section{Native language}

Table 11

\begin{tabular}{cccccc}
\hline Participants & Pahari & Urdu & Punjabi & English & Others \\
\hline Men & $100 \%$ & $0 \%$ & $0 \%$ & $0 \%$ & $0 \%$ \\
Women & $100 \%$ & $0 \%$ & $0 \%$ & $0 \%$ & $0 \%$ \\
\hline
\end{tabular}

Most of the people whom we interviewed were of the parents' age and when they were born and bred, there was no such trend of language shift. Therefore, their parents transferred the native Pahari language to them. Even the school was also not a hurdle. This problem was the latest development. So my participants were of the view that their native language was Pahari, although most of them could speak Urdu and other languages too like one additional language Punjabi. 
However, when we asked them about their children, they said that most of them spoke Urdu and it showed how a shift had taken place from the parent generation to the kids' generations. The following table, thus, illustrates the use of language by the parents to their children.

\section{Language spoken to children}

Table 12

\begin{tabular}{cccccc}
\hline Participants & Pahari & Urdu & Punjabi & English & Others \\
\hline Men & $18 \%$ & $75 \%$ & $2 \%$ & $5 \%$ & $0 \%$ \\
Women & $15 \%$ & $80 \%$ & $1 \%$ & $4 \%$ & $0 \%$ \\
\hline
\end{tabular}

Upon my inquiry regarding the use of language to their children, most of the parents said that they spoke Urdu with their children. This ratio is 75 to 80 percent. We have observed that even the relatively poor parents having fewer resources were inclined to speak Urdu with their children. Only 15 to 18 percent of people said that they were also transmitting Pahari to their children. We found Pahari in a few families. Though Pahari was still spoken but it was spoken among the parents' generation or the parents' generation and grandparents' generation. When we asked this question why they spoke Urdu and not Pahari a male participant said;

"Everybody is doing this, there is no reason we should lag". While on the other hand, a supporter of the Pahari language said;

"It has become a fashion to speak Urdu with children".

The transmission practice was low among the participants. Therefore, it appeared that after one generation, the use of Urdu would be there in the daily communication among the people living in these households. The following table gives us an idea of the language spoken among the parents' generation.

Language spoken among themselves (Parents to Parents or grandparents)

Table 13

\begin{tabular}{cccccc}
\hline Participants & Pahari & Urdu & Punjabi & English & Others \\
\hline Men & $67 \%$ & $26 \%$ & $2 \%$ & $5 \%$ & $0 \%$ \\
Women & $60 \%$ & $35 \%$ & $1 \%$ & $4 \%$ & $0 \%$ \\
\hline
\end{tabular}

The participants of the sample believed that they used Pahari among themselves. Among men,

26 while among women 35 percent said that they spoke Urdu with each other. The rest of the people said that they used Pahari among themselves for communication. This is a positive thing that Pahari is being used by the people of the families. However, the discouraging fact is that they speak Urdu with their children. So after one generation, the use of Urdu will likely dominate their households. In this way, it can be said that threat of language decline is still present. The following table shows whether the things which represent Pahari culture are still there after urbanization or they have been ignored and put into oblivion.

Table 14

Songs, folktales, and riddles in Pahari

\begin{tabular}{ccc}
\hline Participants & Preserved & Lost \\
\hline Men & $10 \%$ & $90 \%$ \\
Women & $12 \%$ & $88 \%$ \\
\hline A very few &
\end{tabular}

A very few participants said that things related to culture are still preserved. We asked them questions about the presence of songs, folktales, and riddles in their culture. Around 90 percent said that they used to listen to these songs, folktales, and riddles during their childhood. But for a long time, they have not been in contact with such a thing. Therefore, these people showed their ignorance about that. Even the elderly people said that they had forgotten all that. We could only get a few pieces of folk literature from my sample. It was a threatening thing for language vitality when it loses all these accessories. So it becomes natural that a language is also under threat like some other things as a result of urbanization.

\section{Conclusion}

The discussion above reveals that urbanization plays a vital role in curtailing the growth of native language and its essential components like songs, poetry, literature, riddles, and folktales. Cities have economic attractions for the people at the cost of their native language and culture. Here people make a deliberate choice of either protect their language by living in rural areas or going to the cities for better living and economic benefits at the cost of their culture and language. 
Moreover, there is a craze, the researcher observed among the parents to adopt only Urdu or only English for their children. This may be called modernity snobbery or their apprehension of the demand of the times. They say that it is necessary to learn these languages for the future of their kids. So, a situation of this kind emerges as a result of that.

As far as schools are concerned, they also cause a lot of harm apart from other disadvantages of urbanization. The state wants to create homogenous communities. The state sometimes does this through an institutionalized way. The state education and schooling system is designed to demean the local cultures and promote the national culture and language. In-state schools inculcate a sense of disgust for their native culture. But these local languages do possess a worth because they are best for multiple types of users within the community. The community members have the confidence of possessing the feeling of having a heritage, the literary history, and oral traditions related to that indigenous language. So the state education, onslaught of foreign culture refutes one's right to choose a culture and language which is best for them.

There is also a concept of one nation, a united people, one language, and culture in the world and it has been helping in curtailing the native languages and cultures which are diverse and multidimensional. Keeping in view all these factors mentioned in this paper, the result is in the shape of language and culture decline which is an embarrassing thing for a culture rich with oral traditions but lacking written record. The migration to the cities and migration from rural to urban life is largely responsible for this shift and decline.

\section{References}

Abbasi, M. G. \& Asif, S.I. (2010). Dilemma of usage and transmission - A sociolinguistic Investigation of Dhundi-Pahari in Pakistan. Language in India, 10 (197-214).

Arif, G. M. \& Hamid, S. (2009). Urbanization, city growth, and quality of life in Pakistan: European Journal of Social Sciences - Volume 10, Number 2 (2009).

Assemi et al, (2012). Culture Within Language: 2012 International Conference on Language, Medias and Culture IPEDR vol.33 (2012) (C) (2012) IACSIT Press, Singapore

Gleasar, E. \& Joshi-Ghani, A.(2014). The Urban Imperative: Toward Shared Prosperity. The World Bank Sustainable Development Network, Policy Research Working Paper: Urban and Disaster Risk Management Department May, 2014.

Gumus, Erdal. (2004), Crime in Urban Areas: An Empirical Investigation. Akdeniz. 1.1. B.F, Dergisi, Volume 7, pp. 98-109.

Haider, M. \& Haider, I. (2006). "Urban Development in Pakistan"In Urbanization and sustainability in Asia: Case Studies on best practice approaches to Sustainable Urban and regional development. Pp.245-272 (chapter 10) A .D Bank, Manila, Philippines.

Haq, R. (2009, September 12). Urbanization in Pakistan Highest in South Asia. Retrieved from Haq's Musings: http://www.riazhaq.com/2009/09/urbanization-in-pakistan-highest-in.html

Illahi, M. (N.A). Taskforce report on Urban Development: Planning commission Islamabad.

Ishtiaq, M. (1999). Language shifts among the scheduled tribes in India: A geographical study. Delhi: Motilal Banarsidass Publishers.

Jorgensen, D.L. (1989). Participant Observation: A Methodology for Human Studies. Newbury Park, CA: Sage Publications.

Kashmiri, L. (2006).Khayaban-e-Murree. Rawalpindi: Babar Booksellers.

Macionis, J. J. (2006). Population, Urbanization, and Environment. In J. M. John, Sociology (p. 569). Delhi: Dorling Kindersley.

Memon, R. (2006). "Determinants and Trends of International Migration in Pakistan", International Labor Migration in Pakistan, Institute of Developing Economies, Japan External Trade Organization, Japan.

World Bank. (2002). Poverty in Pakistan: Vulnerabilities, Social Gaps, and Rural Dynamics, Pakistan Poverty Assessment, Washington DC. 